\title{
Smartphone Application Usage Patterns in Individuals with High Bedtime Procrastination: A Preliminary Study
}

\author{
Sonhye Jeoung, Sooyeon Suh \\ Department of Psychology, Sungshin Women's University, Seoul, Korea
}

\author{
취침시간 지연행동군의 스마트폰 어플리케이션 사용 양상에 대한 예비연구 \\ 정선혜, 서수연 \\ 성신여자대학교 심리학과
}

Received March 13, 2020

Revised April 13, 2020

Accepted April 22, 2020

Address for correspondence

Sooyeon Suh, $\mathrm{PhD}$

Department of Psychology,

Sungshin Women's University,

2 Bomun-ro 34da-gil,

Seongbuk-gu, Seoul 02844,

Korea

Tel: $+82-2-920-7215$

Fax: +82-2-920-2040

E-mail: alysuh@sungshin.ac.kr
Objectives: Bedtime procrastination is defined as going to bed later than intended, without having external reasons for doing so. According to previous studies, bedtime procrastination is strongly associated to usage of smart devices before bedtime. However, there is a lack of in-depth research about the function of smartphone usage before bedtime, and which applications are used frequently in association with bedtime procrastination. Therefore, the current study, preliminary research, investigates the usage patterns of smartphone applications of individuals with high levels of bedtime procrastination. Methods: Participants consisted of 20 adults (female $=80 \%$, age $=20.9 \pm 2.05$ years) who scored higher than 33 on the Bedtime Procrastination Scale. All participants completed a 7-day sleep diary, Insomnia Severity Index, and the Center for Epidemiological Studies Depression Scale. On the sleep diary, participants were asked to track the specific type of smartphone application they used and time they engaged in the specific application prior to bedtime. Results: Among the different main categories, bedtime procrastinators spent significantly more time on communication and leisure prior to bedtime. In addition, the correlation between depression and amount of time spent watching movie/television/video, and between insomnia severity and time spent communicating through cellphone messenger service were significant. Conclusions: The results of this study provide insight into which smartphone applications bedtime procrastinators spend the most time prior to bedtime. The results suggest that the main functions of using their cell phone prior to bedtime are for entertainment and social interaction.

J Sleep Med 2020;17(1):49-57

\section{서 론}

수면은 인간의 삶에 있어 불가분의 관계이다. 불충분한 수 면은 개인의 인지적 기능 및 수행능력의 손상을 초래하며, 우울과 자살사고 등의 부정적 정서와 사고를 유발한다. ${ }^{1-3}$ 또 한 비만과 당뇨병을 포함한 주요 만성 질환의 위험 요인이 될 수 있으며, 기타 신체적 질병의 발병 위험을 증가시킨다. 4.5 즉, 수면은 인간의 신체 및 정서적 안녕을 포함한 생활 전반에 중요한 영향을 미치고, 인간이 정상적으로 기능하기 위해 취

This is an Open Access article distributed under the terms of the Creative Commons Attribution Non-Commercial License (https://creativecommons.org/licenses/by-nc/4.0) which permits unrestricted non-commercial use, distribution, and reproduction in any medium, provided the original work is properly cited.
해야 할 필수적인 건강행동이다. ${ }^{6}$ 그렇지만 네덜란드 일반 성인 인구 2,431명을 대상으로 한 연구 결과에 따르면 전체 표본 50\% 이상이 일주일 중 평균 2일 이상의 수면 부족을 보 고하였다. 또한 미국 성인 인구 $25.9 \%$ 가 빈번한 수면 부족을 경험한다고 보고하였다. 즉, 현대인들의 상당수는 충분한 수 면을 취하지 못해 수면 부족의 고통을 호소한다. 이러한 현대 인들의 수면 부족을 유의미하게 예측하는 요인으로 2014년에 새롭게 제시된 개념이 취침시간 지연행동(bedtime procrastination)이다. ${ }^{8}$

취침시간 지연행동은 외부적인 요인이 부재함에도 불구하 고 개인이 의도했던 시간보다 늦게 잠자리에 드는 지연행동 을 의미한다. 즉, 개인의 자발적인 의도로 취침시간을 지연 
하는 행동을 뜻한다. 지연행동이라는 개념은 지연으로 인한 부정적인 결과가 예상됨에도 불구하고, 자발적으로 해야 할 일이나 과제를 미루는 것으로 정의된다. ${ }^{9,10}$ Tice와 Baumeister의 연구에 따르면 지연행동을 하는 학생들은 스트레스 수 준이 더 높고, 신체 질병의 발병률이 더 높은 것으로 나타났 다. ${ }^{11}$ 또한 지연행동을 할수록 저조한 수행 실적을 보이고 부 정적 기분과의 관련성이 있음이 보고되었다. ${ }^{12,13}$ 이처럼 지연 행동의 부정적인 영향들이 개인의 삶의 다양한 영역에 영향 을 미칠 수 있음에도 불구하고 지연행동은 학업적 영역에 대 한 연구가 주를 이루어 왔다. ${ }^{914}$ 하지만 최근 연구에서 채소 섭취, 신체 활동, 치료를 위해 병원에 방문하는 것과 같은 건 강행동 영역과 지연행동 간의 관련성이 확인되었다. ${ }^{15,16}$ 이에 따라 지연행동의 영역을 확장시켜 ‘수면'이라는 건강행동 영역 에 접목하여 새로이 제시된 개념이 취침시간 지연행동이다.

취침시간 지연행동을 하는 사람들은 수면에 대한 높은 불 만족감과 피로도를 경험한다.7, 즉, 취침시간 지연행동은 개 인의 전반적인 수면에 부정적인 영향을 미친다. 또한 취침시 간 지연행동 수준이 높을수록 더 우울하고 불안한 특성을 보 이는 동시에 낮은 자기 통제력과도 관련이 있는 것으로 나타 났다. 7,8,17 또한, 취침시간 지연행동은 취침 전 잠자리에서의 스마트폰을 포함한 미디어 기기 사용과 관련성이 깊다. 스마 트폰의 등장으로 인해 현대인들의 스마트폰 이용시간은 꾸준 히 증가하고 있다. 2011년에는 불과 24\%였던 개인의 스마트 폰 보유율이 2014년에 80\%까지 증가하는 등 스마트폰의 보 유율이 급속도로 증가하고 있는 추세다. ${ }^{18}$ 편리하고 접근성 이 좋은 스마트폰의 보급은 현대인들에게 있어 다양한 생활 양식의 변화를 초래했다. 특히 미디어 기기를 사용할 수 있는 시공간의 제약이 감소됨에 따라 현대인들이 취침 전 잠자리 에서까지 스마트폰을 사용하는 양상이 만연해지고 있으며, ${ }^{19}$ 취침시간 지연행동이라는 개념이 이러한 현상을 반영하고 있 다. 미국인 1,508 명을 대상으로 수행한 연구에서 10 명 중 9 명이 취침 전 잠자리에서 전자 미디어 기기 사용을 보고하였으며, ${ }^{20}$ 현대인의 취침 전 시간은 전자 미디어 기기를 사용하는 시간 으로 채워지고, 텔레비전 시청과 스마트폰 사용이 취침 전 가장 많이 사용하는 활동으로 보고된 바 있다. ${ }^{21}$ 뿐만 아니라 최근에 수행된 취침시간 지연행동에 따른 생활시간 사용 조 사 연구에서는, 취침 3 시간 전 스마트폰을 사용한 여가활동 에 많은 시간을 소비할수록 취침시간 지연행동을 더 많이 보이고, 취침시간 지연행동 고집단이 하위집단에 비해 하루 중 스마트폰을 사용한 활동에 시간을 더 많이 할애하며, 특 히 취침 직전의 시간대에 그러한 활동이 더 많이 이루어지는 것으로 보고되었다. ${ }^{17}$ 이러한 취침 전 스마트폰 및 미디어 기 기 사용은 높은 수준의 피로도와 불면증 심각도, 늦은 기상
시간과 관련이 있는 것으로 보고되었다. ${ }^{22,23}$ 또한 대학생 254 명을 대상으로 한 연구에서는 취침 전 전자 미디어 기기 사용 이 총 수면시간의 감소와 늦은 취침시간을 예측하는 요인으 로 확인되었다. ${ }^{24}$

이처럼 취침시간 지연행동과 취침 전 다양한 미디어 기기 사용의 관련성에 대한 연구 결과에도 불구하고, 취침시간 지 연행동을 하는 사람들이 취침시간 전에 어떤 특정 미디어 기 기를 사용하여 어떠한 활동을 하는지에 대한 세부 사용 양상 에 대한 연구는 부족한 실정이다. 특히, 선행연구에서 취침시 간 지연행동 고집단이 취침 3 시간 전의 스마트폰 사용이 시 간적으로는 유의미하게 많은 양상을 보인 것을 확인하였으 나, 세부적으로 어떠한 양상을 통해 시간을 사용하고 있는지 에 대한 탐색은 다뤄지지 않았다. ${ }^{17}$ 이에 더불어서 현대 사회 의 스마트폰 보유율이 다른 미디어 매체에 비해 전 연령대에 서 압도적으로 높은 특징을 보이고 있음에도 불구하고, ${ }^{25}$ 취침 시간 지연행동군의 스마트폰의 세부 사용 양상에 초점을 맞 춘 심층적인 연구가 부재한 실정이다. 국내에서 스마트폰의 과다 사용의 매개 효과를 확인하기 위한 변수로서의 취침시 간 지연행동을 다룬 선행연구가 있지만, 어떠한 스마트폰 사 용양상을 보이는지에 대해서는 다뤄지지 않았다. ${ }^{26}$ 또한 스마 트폰 사용이 많을수록 우울 수준과 불면증 심각도가 높은 것 으로 보고되고 있으며, 특히 수면 전 침대에서 과도한 전자 매체를 사용하는 것은 수면장애와 우울증의 위험 요소이며, 수면 전 전자매체 사용시간이 길어질수록 수면시간이 짧아 지는 것으로 확인되었다. ${ }^{27-30}$ 뿐만 아니라 평균 스크린 시간 이 길수록 수면시간이 짧아지고, 수면 효율성과 수면의 질이 저하되며 긴 수면 잠복기를 나타낸다는 연구 결과 또한 보고 되고 있다. ${ }^{31}$ 이처럼 수면 전 스마트폰을 비롯한 미디어 기기 의 사용이 수면과 정서에 부정적인 영향을 미친다는 다양한 선행연구가 존재함에도 불구하고 구체적으로 어떠한 스마트 폰 사용 양상이 이러한 임상적인 지표들과 관련이 있는지에 대한 세부적인 연구 또한 부족한 실정이다.

따라서 본 연구는 이러한 선행연구들을 보완하기 위해 기 존의 연구에서 세부적으로 파악하지 못했던 취침시간 지연 행동군의 스마트폰 세부 사용 양상을 예비적 수준에서 탐색 해 보고자 한다. 즉, 취침시간 전의 단순한 스마트폰 사용량 탐색에서 나아가, 어떠한 어플리케이션 활용을 통해 스마트 폰 사용시간이 채워지고 있는지에 대해 세부적으로 탐색하 고자 한다. 더 나아가 스마트폰 세부 사용 양상에 따른 우울 과 불면증 심각도 수준의 관련성을 확인해 보고자 한다. 이 를 통해 취침시간 지연행동에 대한 이해를 높이고, 이들의 스마트폰 사용 동기와 욕구를 파악하여 추후 치료적 개입 방 법을 마련하는 데 있어 기초적인 자료를 제공하고자 한다. 


\section{방 법}

\section{연구 대상}

본 연구의 대상자는 초기 성인기에서 지연행동이 가장 많 이 나타난다는 선행연구에 따라, ${ }^{32} 20$ 대 성인 남녀 20명을 대 상으로 수행되었으며, 성신여자대학교 생명윤리심의위원회 의 승인(SSWUIRB 2018-020)을 받았다. 연구 참가자는 온 라인과 오프라인 홍보 게시물을 통해 자발적으로 연구 참여 의사를 밝힌 사람들을 대상으로 모집하였다. 연구 참여 기준 은 취침시간 지연행동 척도(Bedtime Procrastination Scale, $\mathrm{BPS})$ 의 절단점을 사용한 연구에 근거하여 취침시간 지연행 동 척도 33점 이상의 점수를 충족하는 취침시간 지연행동이 높은 사람들을 대상으로 하였다. ${ }^{17}$ 총 274 명이 참여 신청 질 문지를 완료하였고, 다음 기준에 따라 250 명이 제외되었다 1) BPS 33점 이하인 자, 2) 자살시도 과거력이 있는 자, 3) 양 극성장애로 진단받은 자, 4) 조현병으로 진단받은 자, 5) 기타 수면장애로 진단받은 자, 6) 수면 관련 약물을 복용 중인 자, 7) 교대근무를 하는 자, 8) 현재 심리치료 진행 중인 자. 더불 어 4명의 연구 참가자가 연구 참여 시작 전에 연구 참여 의사 를 철회하였다.

\section{측정 도구}

\section{수면일지(Sleep diary)}

참가자들의 스마트폰 어플리케이션 사용 양상을 분석하기 위해 7일간의 수면일지를 수집했으며, 수면일지를 통해 어 플리케이션의 범주별로 하루 평균 시간을 분 단위로 계산하 였다. 모든 참가자들이 수면일지 작성을 완료하였다. 수면일 지에는 전날 밤 수면에 대한 세부 정보 및 취침 전 3시간 동 안 사용한 특정 스마트폰 어플리케이션과 각각의 사용시간 을 작성하도록 하였다. 또한 어플리케이션 사용시간을 정확 하게 측정할 수 있도록 스마트폰 세부 사용시간을 측정하는 어플리케이션(예, 너는 얼마나 쓰니?, 아이폰 스크린 타임)을 참가자들에게 안내하고 사용하도록 하였다.

\section{스마트폰 어플리케이션 범주별 분류}

스마트폰 어플리케이션 범주별 분류는 한국과학기술정보 통신부의 스마트폰 이용 콘텐츠 분류 체계를 토대로 본 연구 의 목적에 따라 재구성한 분류 체계를 사용하였다. ${ }^{33}$ 스마트 폰 어플리케이션을 대, 중, 소분류의 세 가지 범주로 분류하 였다. 대분류는 스마트폰 어플리케이션의 주요 사용 목적에 따라 커뮤니케이션, 여가, 생활관리를 포함한 9개의 범주들 로 분류하였으며, 중분류는 메신저, 소셜 네트워크 서비스 (social network service, SNS), 이메일 등과 같이 대분류 항 목에 해당하는 활동들을 20 개의 범주로 세분화하여 분류하 였다. 또한 대 - 중분류에 속하는 특정 어플리케이션의 사용 량 순에 따라 1 위부터 10 위까지 소분류로 분류하였다(예, 카 카오톡, 인스타그램, 페이스북).

\section{한국판 불면증 심각도 척도(Korean version}

of Insomnia Severity Index, ISI-K)

본 연구는 참가자들의 불면증 심각도를 측정하기 위해 Bastien 등이 개발하고, ${ }^{34}$ Cho 등이 타당화한 한국판 불면증 심각도 척도(ISI-K)를 사용하였다. ${ }^{35}$ 본 척도는 0 4까지의 5 점 리커트 척도를 포함한 총 7 개 문항으로 구성되어 있으며, 최근 2주간 경험한 불면증의 심각도를 측정한다. 총점은 0 28 점으로 점수가 높을수록 불면증이 심각함을 의미한다. ISI-K 에서는 15점부터 임상적 불면증으로 간주한다. Bastien 등의 연구에서 내적일치도 계수(Cronbach's $\alpha$ )는 0.74 이며, ${ }^{34} \mathrm{Cho}$ 등의 타당화 연구에서 내적일치도 계수(Cronbach's $\alpha$ )는 0.92 로 나타났다. ${ }^{35}$

\section{우울 척도(Center for Epidemiologic Studies-}

Depression Scale, CES-D)

본 연구는 Radloff가 일반 인구의 우울을 측정하기 위해 개발한 CES-D를 Chon 등이 번안한 한국판 우울 척도를 사 용하였다. ${ }^{36,37}$ 해당 척도는 4 문항의 역채점 문항을 포함하여 $(4,8,12,16)$ 총 20 문항으로 구성되어 있다. 각 문항은 0 3까 지의 4점 리커트 척도로, 지난 1주간 경험한 우울 증상의 빈 도를 측정한다. 총점은 0 60점으로 점수가 높을수록 우울 수 준이 높은 것을 의미한다. 척도의 원논문에서 제시한 절단점 은 16점이다. Chon 등의 연구에서 내적일치도 계수(Cronbach's $\alpha$ )는 0.91 로 나타났다. ${ }^{37}$

\section{자료 분석}

본 연구의 자료 분석을 위해 SPSS 21.0 version(IBM Corp., Armonk, NY, USA)과 RStudio 프로그램 3.6.1 version (RStudio, Inc., Boston, MA, USA)을 사용하였으며, 구체적 인 분석 방법은 다음과 같다.

첫째, 연구 참가자들의 인구통계학적 특성과 스마트폰 총 사용량을 포함한 어플리케이션 사용 양상을 분석하기 위하 여 기술통계를 사용하여 분석하였다.

둘째, 스마트폰 어플리케이션 사용 양상 데이터를 시각화 하기 위해 RStudio 프로그램을 활용하여 Heatmap을 구축하 였다. Heatmap은 수집된 데이터를 시각화하여 나타내는 그 래프를 의미한다. 
셋째, 특정 스마트폰 어플리케이션 사용시간과 주요 임상 지표 및 수면지표 간의 관련성을 비모수 통계분석 방법인 Spearman 상관분석을 통해 확인하였다.

\section{결 과}

\section{인구통계학적 특성}

본 연구 참가자 $(\mathrm{n}=20)$ 의 연령 평균은 20.9 세 $( \pm 2.05)$ 였으 며, 여성 $80.0 \%(\mathrm{n}=16)$ 와 남성 $20.0 \%(\mathrm{n}=4)$ 를 포함하였다. 교 육 수준은 $85.0 \%(\mathrm{n}=17)$ 로 대학교 재학 중이 가장 많았고, $5.0 \%(\mathrm{n}=1)$ 가 학사학위 취득, $10.0 \%(\mathrm{n}=2)$ 가 석사학위 이상이 었다. 연구 참가자 대다수인 18명(90.0\%)이 미고용 상태였으 며, 20명(100\%)은 미혼으로 나타났다(Table 1).

\section{스마트폰 어플리케이션 사용 양상}

\section{취침 3 시간 전 스마트폰 사용 총량}

연구 참가자들의 스마트폰 세부 사용 양상을 분석하기 전 에 앞서, 취침시간 전 3 시간 동안의 스마트폰 평균 사용량에 대한 분석결과를 Table 2에 기술하였다. 분석 결과, 연구 참가 자들은 평균적으로 취침시간 전 3시간 중 절반 이상을 스마트 폰을 사용하며 시간을 보내는 것으로 나타났다[Mean=92.75; standard deviation(SD)=30.24분].

\section{대분류 영역에 따른 사용 양상}

대분류 영역에 따라 구분한 연구 참가자들의 취침 3 시간 전의 스마트폰 어플리케이션 사용 양상 분석 결과를 Table 2

Table 1. Demographics of participants

\begin{tabular}{lcc}
\hline & $\mathrm{n}(\%)$ & Mean $(\mathrm{SD})$ \\
\hline Sex & $16(80.0)$ & \\
$\quad$ Female & $4(20.0)$ & $20.9( \pm 2.05)$ \\
$\quad$ Male & \\
Age, years & \\
Education & $17(85.0)$ & \\
Undergraduate & $1(5.0)$ & \\
Bachelor's degree & $2(10.0)$ \\
$\quad$ Master's or higher & \\
Marital status & $20(100)$ \\
Single & \\
Job & $2(10.0)$ \\
Employment &
\end{tabular}

SD: standard deviation
에 기술하였다. 분석 결과, 취침시간 지연행동군은 스마트폰 어플리케이션 대분류 영역 중 커뮤니케이션(Mean=38.80; $\mathrm{SD}=31.04$ 분), 여가(Mean=34.81; SD=29.80분), 인터넷 서핑 (Mean=11.28; $\mathrm{SD}=25.56$ 분) 순으로 많이 사용하는 것으로 나 타났다. 반면, 금융(Mean $=0.00 ; \mathrm{SD}=0.00$ 분) 영역의 어플리 케이션은 가장 사용하지 않는 스마트폰 어플리케이션 영역 으로 확인되었다. 대분류 영역에 따른 데이터를 시각화한 결 과는 커뮤니케이션과 여가 영역에 유의하게 많은 데이터가 집중되었으며, 인터넷 서핑과 전화 통화 또한 비교적 많은 데이터가 집중된 것으로 나타났다(Fig. 1).

\section{중분류 영역에 따른 사용 양상}

연구 참가자들의 스마트폰 어플리케이션 사용 양상을 중 분류 영역으로 세분화한 결과를 Table 3에 제시하였다. 중분 류 영역 중에서는 영화/텔레비전/동영상 시청(Mean=27.84; $\mathrm{SD}=33.23$ 분), $\mathrm{SNS}$ (Mean=20.55; $\mathrm{SD}=26.97$ 분), 메신저 (Mean=18.25; SD=23.53분)에 주로 많은 시간을 소비하는 것 으로 나타났으며, 해당 활동들은 모두 대분류 카테고리 영역 중 많은 사용량을 나타냈던 여가와 커뮤니케이션 영역에 포 함되어 있는 활동들이었다.

\section{소분류 영역에 따른 사용 양상}

스마트폰 어플리케이션 소분류 영역은 연구 참가자들이 가장 많이 사용하는 것으로 나타난 어플리케이션을 1 위부터 10 위까지 분석한 결과를 나타낸다. 분석 결과, 유튜브(Mean= 21.55; $\mathrm{SD}=33.32$ 분), 카카오톡(Mean=18.25; $\mathrm{SD}=23.53$ 분), 전 화 통화(Mean=6.42; $\mathrm{SD}=12.65$ 분) 순으로 많이 사용하는 것 으로 확인되었다. 소분류 영역에 대한 전체 결과는 Table 4

Table 2. Smartphone usage for 3 hours before bedtime (main category of smartphone application)

\begin{tabular}{lccc}
\hline \multicolumn{1}{c}{ Main category } & Mean $(\mathrm{SD})^{*}$ & Max & Min \\
\hline Communication & $38.80(31.04)$ & 108.33 & 0.00 \\
Leisure & $34.81(29.80)$ & 142.86 & 0.71 \\
Web surfing & $11.28(25.56)$ & 85.57 & 0.00 \\
Telephone call & $6.42(12.65)$ & 43.08 & 0.00 \\
Online transaction & $1.00(4.47)$ & 20.00 & 0.00 \\
Life management & $0.25(0.84)$ & 3.57 & 0.00 \\
Information retrieval & $0.19(0.61)$ & 2.50 & 0.00 \\
$\quad$ and utilization & & & \\
Finance & $0.00(0.00)$ & 0.00 & 0.00 \\
Other & $0.36(1.60)$ & 7.14 & 0.00 \\
Total usage $^{\dagger}$ & $92.75(30.24)$ & 145.71 & 32.14 \\
\hline
\end{tabular}

*units per minute; for a day, ${ }^{\dagger}$ smartphone total usage for 3 hours before bedtime. SD: standard deviation 


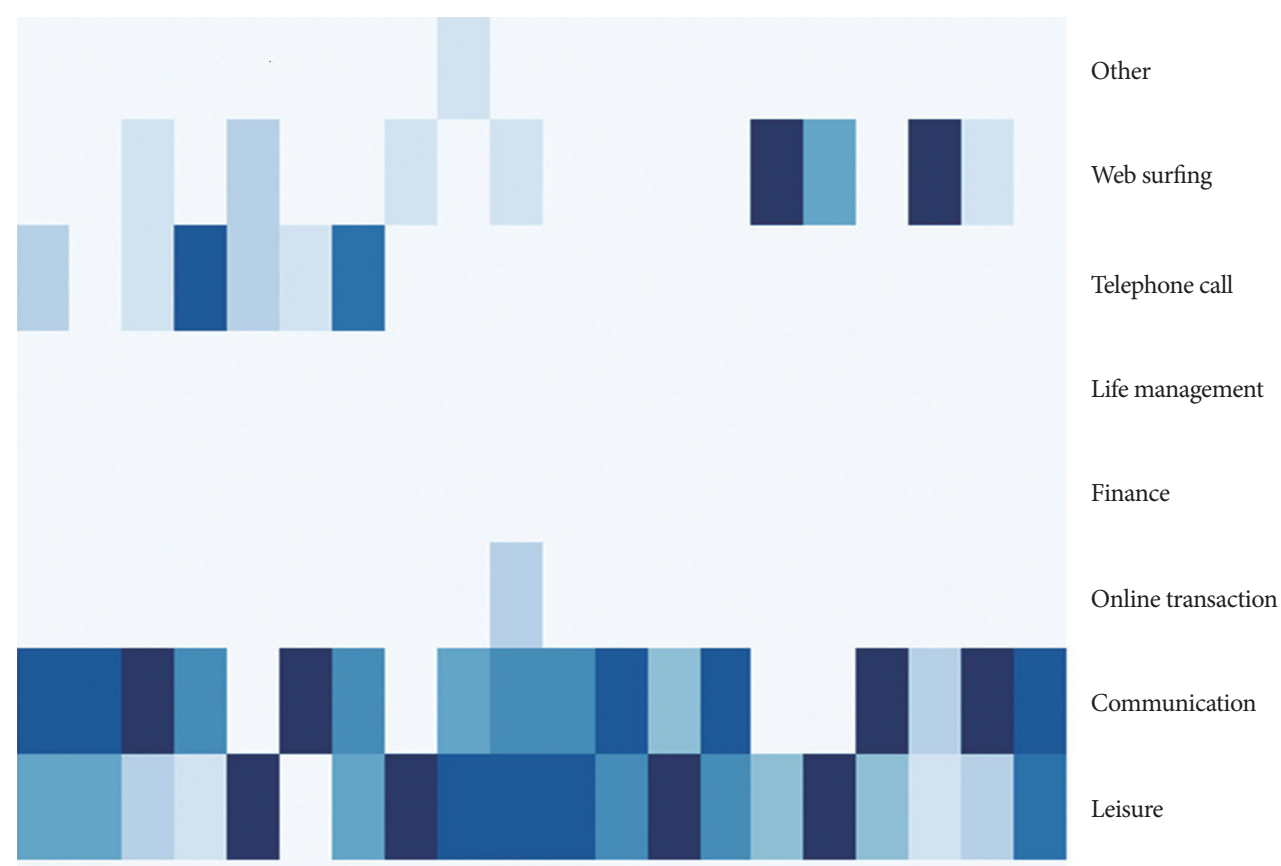

Information retrieval and utilization

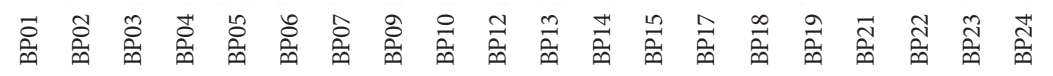

Figure 1. Smartphone usage for 3 hours before bedtime (main category).

Table 3. Smartphone usage for 3 hours before bedtime (sub-category)

\begin{tabular}{|c|c|c|c|c|}
\hline Main category & Sub-category & Mean (SD)* & Max & Min \\
\hline \multirow[t]{3}{*}{ Communication } & E-mail & $0.00(0.00)$ & 0.00 & 0.00 \\
\hline & Messenger & $18.25(23.53)$ & 90.71 & 0.00 \\
\hline & SNS & $20.55(26.97)$ & 108.33 & 0.00 \\
\hline \multirow[t]{6}{*}{ Leisure } & Game & $4.21(6.90)$ & 21.25 & 0.00 \\
\hline & Adult contents & $0.00(0.00)$ & 0.00 & 0.00 \\
\hline & Movie/television/video & $27.84(33.23)$ & 142.86 & 0.00 \\
\hline & Music & $0.43(1.26)$ & 5.00 & 0.00 \\
\hline & E-book/webtoon & $2.33(4.04)$ & 12.50 & 0.00 \\
\hline & Sports betting & $0.00(0.00)$ & 0.00 & 0.00 \\
\hline Web surfing ${ }^{\dagger}$ & Web surfing & $11.28(25.56)$ & 85.57 & 0.00 \\
\hline Telephone call & Telephone call & $6.42(12.65)$ & 43.08 & 0.00 \\
\hline Online transaction $\ddagger$ & Online transaction & $1.00(4.47)$ & 20.00 & 0.00 \\
\hline Life management & Life management & $0.25(0.84)$ & 3.57 & 0.00 \\
\hline \multirow[t]{5}{*}{ Information retrieval and utilization } & News & $0.13(0.56)$ & 2.50 & 0.00 \\
\hline & Study/business & $0.00(0.00)$ & 0.00 & 0.00 \\
\hline & Education/learning & $0.00(0.00)$ & 0.00 & 0.00 \\
\hline & Product/service $§$ & $0.00(0.00)$ & 0.00 & 0.00 \\
\hline & Transport/location & $0.06(0.28)$ & 1.25 & 0.00 \\
\hline Finance & Finance & $0.00(0.00)$ & 0.00 & 0.00 \\
\hline Other & Other & $0.36(1.60)$ & 7.14 & 0.00 \\
\hline
\end{tabular}

*units per minute; for a day, ${ }^{\dagger}$ visiting various sites on the Internet without specific purpose, ${ }^{\ddagger}$ selling or purchasing goods/services (ex, reservation, second-hand transaction, etc.), §search for product/service information. SD: standard deviation, SNS: social network service 
에 제시하였다.

스마트폰 어플리케이션 사용과 임상지표, 수면지표 간의 상관분석

스마트폰 어플리케이션 대분류 영역에 따른 임상지표, 수 면지표 간의 상관분석 결과를 Table 5에 제시하였다. 분석 결

Table 4. Smartphone application usage for 3 hours before bedtime (sub-sub category)

\begin{tabular}{lcrc}
\hline \multicolumn{1}{c}{ Sub-sub category } & Mean (SD)* & Max & Min \\
\hline Youtube & $21.55(33.32)$ & 142.86 & 0.00 \\
Kakaotalk & $18.25(23.53)$ & 90.71 & 0.00 \\
Telephone call & $6.42(12.65)$ & 43.08 & 0.00 \\
Web browser & $6.01(19.14)$ & 85.57 & 0.00 \\
Facebook & $5.87(13.36)$ & 51.43 & 0.00 \\
Online community & $5.42(24.22)$ & 108.33 & 0.00 \\
Firefox & $4.21(18.85)$ & 84.29 & 0.00 \\
College community & $4.03(7.40)$ & 25.00 & 0.00 \\
Watch soccer matches & $3.25(10.04)$ & 35.00 & 0.00 \\
Game & $2.81(6.09)$ & 21.25 & 0.00 \\
\hline
\end{tabular}

*units per minute; for a day. SD: standard deviation
과, 커뮤니케이션 어플리케이션 사용시간과 불면증 심각도 간의 정적상관이 나타났으며 $(\mathrm{r}=0.449, p<0.05)$, 생활관리 어 플리케이션 사용시간과 불면증 심각도 간의 부적상관이 나 타났다 $(\mathrm{r}=-0.470, p<0.05)$. 또한 여가 영역의 어플리케이션 사용시간과 총 수면시간 간의 부적상관을 확인할 수 있었다 $(\mathrm{r}=-0.468, p<0.05)$.

스마트폰 어플리케이션 중분류 영역 중 참가자들이 가장 많이 사용하는 것으로 나타난 5가지의 어플리케이션 영역의 사용시간과 주요 임상지표와의 관련성을 살펴보았다. 분석 결과, 메신저 어플리케이션 사용시간과 불면증 심각도 간의 정적상관이 나타났으며 $(\mathrm{r}=0.570, p<0.01)$, 영화/텔레비전/동 영상 어플리케이션 사용시간과 우울 간의 정적상관이 나타 났다 $(\mathrm{r}=0.482, p<0.05)$. 이에 더불어 전화통화 어플리케이션 과 영화/텔레비전/동영상 시청 어플리케이션 사용시간 간의 부적상관이 나타났다(r=-0.449, $p<0.05)$. 결과는 Table 6에 제시하였다.

\section{고 찰}

본 연구는 높은 수준의 취침시간 지연행동을 나타내는 사

Table 5. Correlation between main category of smartphone application and clinical and sleep indices

\begin{tabular}{|c|c|c|c|c|c|c|c|}
\hline & ISI & CES-D & TST & WASO & SOL & SE & SQ \\
\hline Information retrieval and utilization & -0.141 & -0.171 & -0.224 & -0.183 & 0.241 & -0.309 & 0.167 \\
\hline Leisure & -0.245 & 0.341 & $-0.468^{*}$ & -0.401 & 0.262 & -0.277 & -0.233 \\
\hline Communication & $0.449^{*}$ & 0.023 & 0.154 & 0.343 & 0.033 & -0.105 & -0.293 \\
\hline Online transaction & 0.180 & 0.201 & -0.378 & -0.378 & 0.338 & -0.139 & -0.379 \\
\hline Life management & $-0.470^{*}$ & 0.001 & 0.155 & 0.069 & -0.225 & -0.169 & 0.216 \\
\hline Telephone call & 0.168 & 0.020 & -0.067 & 0.331 & -0.123 & -0.290 & -0.097 \\
\hline Web surfing ${ }^{\dagger}$ & -0.145 & -0.034 & 0.308 & 0.135 & -0.004 & 0.130 & 0.112 \\
\hline Other & -0.321 & -0.181 & -0.229 & -0.040 & -0.100 & -0.298 & -0.220 \\
\hline
\end{tabular}

${ }^{*} p<0.05,{ }^{\dagger}$ visiting various sites on the Internet without specific purpose. ISI: Insomnia Severity Index, CES-D: Center for Epidemiologic Studies-Depression Scale, TST: total sleep time, WASO: wake after sleep onset, SOL: sleep onset latency, SE: sleep efficiency, SQ: sleep quality

Table 6. Correlation between top 5 sub-category of smartphone application and clinical indices

\begin{tabular}{|c|c|c|c|c|c|c|}
\hline & 1 & 2 & 3 & 4 & 5 & 6 \\
\hline \multicolumn{7}{|l|}{ ISI } \\
\hline CES-D & 0.404 & & & & & \\
\hline Movie/television/video & -0.143 & $0.482^{*}$ & & & & \\
\hline Messenger & $0.570^{* *}$ & 0.165 & -0.122 & & & \\
\hline SNS & 0.195 & -0.339 & -0.310 & -0.124 & & \\
\hline Telephone call & 0.168 & 0.020 & $-0.449^{*}$ & 0.439 & -0.194 & \\
\hline Web surfing ${ }^{\dagger}$ & -0.145 & -0.034 & 0.037 & -0.181 & -0.312 & -0.235 \\
\hline
\end{tabular}

${ }^{*} p<0.05,{ }^{* *} p<0.01,{ }^{\dagger}$ visiting various sites on the Internet without specific purpose. ISI: Insomnia Severity Index, CES-D: Center for Epidemiologic Studies-Depression Scale, SNS: social network service 
람들의 스마트폰 어플리케이션 사용 양상에 대한 예비연구 를 실시하였다. 이를 위해 연구 참가자들의 인구통계학적 정 보, 수면일지를 통한 스마트폰 세부 사용 양상, 스마트폰 어플 리케이션 사용에 따른 임상 및 수면지표의 관련성을 확인하 였으며 이에 따른 연구 주요 결과 요약과 의의는 다음과 같다.

첫째, 취침시간 지연행동군의 스마트폰 어플리케이션 세 부 사용 양상을 확인한 결과 대, 중, 소분류 모두에서 동일하 게 커뮤니케이션과 여가 영역의 어플리케이션 사용량이 가 장 많은 것으로 나타났다. 이러한 연구 결과는 취침시간 지 연행동 상위집단이 교제 및 여가활동에 유의하게 더 많은 시 간을 소비하는 것으로 나타난 선행연구 결과와 일치한다. ${ }^{17}$ 또한 취침시간 지연행동군이 가장 많은 시간을 소비하는 스 마트폰 어플리케이션 종류에 대한 정보를 제공함과 동시에 취침 전 스마트폰 사용의 주요 기능이 오락과 사회적 상호작 용임을 설명할 수 있으며, 이러한 결과는 취침시간 지연행동 의 기제에 대해 새로운 시사점을 제공할 수 있다. $\mathrm{Oh}$ 의 연구 에서는 SNS 중독 경향성이 높은 사람일수록 더 높은 수준의 우울감과 외로움을 보고하고 대인관계에서의 만족감이 낮은 것으로 보고되었으며, ${ }^{38} \mathrm{Cho}$ 와 $\mathrm{Suh}$ 의 연구에서는 대인관계 에서의 소외가 SNS 중독 경향성과 높은 상관을 보이는 것으 로 확인되었다. ${ }^{39}$ 또한 376 명의 대학생을 대상으로 스마트폰 중독과 사회적 불안 및 외로움의 관계를 조사한 연구에서 개 인의 외로움의 정도와 사회적 불안 수준이 스마트폰 중독을 예측하는 요인으로 확인되었고, 스마트폰을 사용하는 것이 외로움을 경험하는 사람들에게 자가 치료적인 기능을 가질 수 있다는 것을 보고하였다. ${ }^{40}$ 즉, 취침시간 지연행동군이 취 침 전 잠자리에서 사회적 상호작용과 오락의 기능을 가진 어 플리케이션을 가장 많이 사용한다는 것은, 일상 생활에 있어 충족되지 않은 사회적 상호작용과 그로 인해 얻을 수 있는 즐거움을 충족시키고자 하는 행동으로써 취침시간 지연행동 이 나타날 수 있음을 추측해 볼 수 있다.

둘째, 스마트폰 어플리케이션 사용시간과 우울, 불면증을 포함한 임상지표 간의 관계를 살펴보았다. 대분류 영역 분석 결과 불면증 심각도가 높아질수록 커뮤니케이션 영역의 어 플리케이션을 사용하는 시간이 많은 양상을 보였으며, 커뮤 니케이션 영역의 어플리케이션 중에서도 메신저 어플리케이 션을 사용하는 시간이 많을수록 불면증 심각도가 높은 양상 을 보여 선행연구와 일치하는 결과를 보였다..$^{30}$ 또한 가계부, 달력, 목표 관리, 메모, 일기 등과 같은 개인의 생활을 관리하 는 속성을 지닌 생활관리 어플리케이션을 사용하는 시간이 많을수록 불면증 심각도 수준이 낮은 양상을 나타냈다. 이는 개인의 생활을 관리하는 속성의 어플리케이션을 많이 활용 하는 사람일수록 그렇지 않은 사람에 비해 일상생활에서 상
대적으로 자신과 생활을 관리하는 활동에 시간을 많이 할애 한다고 추측해 볼 수 있다. 개인의 일상생활 습관은 신체적 질병이 발생하는 데 있어 영향을 미치고, 특히 자신을 조절 하고 관리하는 특성이 건강 회복 또는 질병 악화에 있어 핵 심적인 변인으로 작용한다. ${ }^{41}$ 즉, 일상생활의 관리 정도는 개 인의 건강과 질병 관리 측면에서 중요한 요인이다..$^{41}$ 뿐만 아 니라 불면증의 일차치료로써 주목받고 있는 인지행동치료의 성공 여부는 환자들이 임상가로부터 권유받은 자기 관리 행 위들에 대한 순응도에 달려있다고 제안하고 있다. ${ }^{42}$ 특히, 환 자에게 건강한 수면을 위한 환경적 요인 및 삶의 방식들에 대한 정보를 제공하고, 권고사항을 교육하는 수면위생 교육 에서는 환자 스스로가 권고사항을 이행하기 위해 개인의 생 활을 관리하는 것이 강조된다. ${ }^{42}$ 즉, 개인의 생활 및 자기관리 능력은 불면증을 비롯한 건강관리 관점에서 중요한 요인으 로서 자리잡고 있으며, 이러한 특징들이 개인의 불면증 심각 도에 영향을 줄 수 있는 것으로 추측해 볼 수 있다. 또한 우 울은 영화/텔레비전/동영상 어플리케이션 사용시간과 유의 한 정적상관을 보였다. 이는 스마트폰을 통해 영화/텔레비 전/동영상을 시청하는 사람일수록 일상적인 생활에서 높은 우울을 보고할 가능성이 높은 것을 시사한다. 또한 침실에서 스마트폰을 사용하여 위와 같은 동영상을 시청하는 것은 높 은 우울을 보고하는 사람들이 밤에 잠이 들도록 돕는 수단으 로 영화나 텔레비전 시리즈를 보기 때문일 수도 있다. 43,44

셋째, 스마트폰 어플리케이션 사용시간과 수면일지로 측 정한 수면지표 간의 관계를 살펴보았다. 그 결과 여가 영역 의 어플리케이션 사용시간과 총 수면시간 간의 부적상관이 확인되었다. 취침시간 지연행동은 현대인의 수면 부족을 유 의하게 예측하는 주요 요인 중 하나로 제시되고 있다. ${ }^{7}$ 또한 Chung 등의 연구에서도 취침시간 지연행동 상위 집단이 하 위집단에 비해 취침 3시간 전 스마트폰을 사용한 여가활동에 많은 시간을 소비하는 것으로 확인되었다. ${ }^{17}$ 이러한 연구 결 과는 현대인들이 취침 전에 스마트폰을 활용한 여가활동을 통해 취침시간 지연행동을 하며, 이로 인해 수면 부족이 발생 할 수 있는 것으로 추측해 볼 수 있다. 즉, 본 연구의 결과 또 한 선행연구와 일치하는 결과로, 여가 영역의 어플리케이션 의 사용시간이 많을수록 취침시간 지연행동 수준이 높아질 수 있으며, 이로 인해 개인의 총 수면시간이 짧아질 수 있음 을 시사한다.

본 연구의 제한점 및 후속연구를 위한 제언은 다음과 같 다. 첫째, 본 연구는 적은 표본 수의 단일집단을 대상으로 취 침시간 지연행동군의 스마트폰 사용 양상에 대한 탐색적 수 준의 예비연구를 진행하였다. 따라서 본 연구 결과를 일반화 하는 데 있어 한계점을 지닌다. 이에 추후 연구에서는 더 많 
은 사례 수를 확보하는 것이 필요하며 취침시간 지연행동 수 준이 낮은 집단을 추가적으로 모집하여 집단별 비교연구를 통해 스마트폰 사용 양상과 그에 따른 취침시간 지연행동의 기제를 검증할 필요성이 제기된다. 더 나아가 두 집단 간의 차이에 대해 탐색하고, 반복 측정이 가능한 연구를 설계하여 검증하는 것도 취침시간 지연행동을 이해하는 데 있어 의미 있는 연구가 될 것으로 사료된다. 둘째, 본 연구에서의 표본 성별이 여성에 다소 치중되어 있다. 따라서 추가적인 남성 표본 모집을 통해 그에 따른 추가 검증과 비교분석의 필요성 이 제기된다. 셋째, 우울과 불면증 심각도를 참가자들의 주 관적인 보고에 의존하여 측정하였다. 즉, 해당 지표가 객관적 으로 측정되지 않아 과소 또는 과대 추정될 가능성을 가지며, 자기 보고로 측정하는 우울은 우울 증상의 단기적인 경과에 대한 정보만을 제공하는 한계점을 지닌다. 따라서 후속연구 에서는 기능적 자기 공명 영상(functional magnetic resonance imaging)과 같은 도구를 활용해 생리적 지표로의 우울을 측 정하거나, 수면다원검사와 액티그라피를 활용하여 불면증 심각도를 측정하는 등 해당 지표들을 객관적으로 측정할 수 있는 방법을 강구하여 연구를 실시할 것을 제안한다.

이러한 한계점에도 불구하고 본 연구는 다음과 같은 의의 를 지닌다. 본 연구는 취침 전 잠자리에서까지 스마트폰을 사용하는 현상이 만연해진 현대 사회의 흐름에 따라 새롭게 제시된 개념인 취침시간 지연행동에 주목하였다. 이에 취침 시간 지연행동군의 스마트폰 세부 사용 양상 조사를 통해 그 들의 동기와 욕구를 탐색하기 위한 연구를 진행하였다. 본 연구를 통해 취침시간 지연행동군의 스마트폰 세부 사용 양 상과 그들의 취침 전 스마트폰 사용의 주요 기능이 오락과 사회적 상호작용임을 추측해 볼 수 있다. 또한 취침시간 지 연행동의 기제가 개인의 충족되지 않은 사회적 상호작용에 대한 욕구에서 기인할 수 있음을 제안했다. 더 나아가 취침 시간 지연행동군이 가장 많이 사용하는 어플리케이션이 사 회적 상호작용과 오락이라는 결과는 치료적 맥락에서도 중 요한 의의를 지닌다. 인지행동치료는 개인의 수면 개선을 위 해 효과적인 개입으로 알려져 있지만, ${ }^{45}$ 취침 전 스마트폰 사 용을 충분히 다루고 있지 않다. 따라서 취침시간 지연행동을 감소시키기 위해서는 취침 전 오락과 사회적 상호작용에 대 한 그들의 욕구를 충족시키는 동시에 스마트폰 사용을 대체 할 수 있는 활동을 식별하여 맞춤화된 개입을 실시하는 것이 중요함을 시사한다. 또한 특정 어플리케이션 사용에 따른 우 울과 불면증 심각도 간의 관련성도 확인할 수 있었다. 즉, 이 러한 연구 결과는 취침시간 지연행동에 대한 효과적인 개입 마련에 있어 개인의 취침 전 스마트폰 사용에 따른 기능과 욕구를 파악하여 맞춤화된 접근이 필요함을 시사하며, 취침
시간 지연행동을 이해하고 그들의 건강행동 증진을 위한 효 과적인 개입 마련을 위해 기초가 되는 자료로 활용되기를 기 대해 볼 수 있다.

\section{Acknowledgments}

This work was supported by the Ministry of Education of the Republic of Korea and the National Research Foundation of Korea (NRF-2018S1A 5A8026807).

\section{Conflicts of Interest}

The authors have no potential conflicts of interest to disclose.

\section{ORCID iDs}

$\begin{array}{ll}\text { Sonhye Jeoung } & \text { https://orcid.org/0000-0003-3433-962X } \\ \text { Sooyeon Suh } & \text { https://orcid.org/0000-0003-0644-8634 }\end{array}$

\section{Author Contributions}

Conceptualization: Sonhye Jeoung, Sooyeon Suh. Data curation: Sonhye Jeoung, Sooyeon Suh. Formal analysis: Sonhye Jeoung, Sooyeon Suh. Investigation: Sonhye Jeoung, Sooyeon Suh. Methodology: Sonhye Jeoung, Sooyeon Suh. Supervision: Sooyeon Suh. Writing_-original draft: Sonhye Jeoung. Writing_-review \& editing: Sooyeon Suh, Sonhye Jeoung.

\section{REFERENCES}

1. Pilcher JJ, Huffcutt AI. Effects of sleep deprivation on performance: a meta-analysis. Sleep 1996;19:318-326.

2. Van Dongen HP, Maislin G, Mullington JM, Dinges DF. The cumulative cost of additional wakefulness: dose-response effects on neurobehavioral functions and sleep physiology from chronic sleep restriction and total sleep deprivation. Sleep 2003;26:117-126.

3. Suh S, Kim H, Yang HC, Cho ER, Lee SK, Shin C. Longitudinal course of depression scores with and without insomnia in non-depressed individuals: a 6-year follow-up longitudinal study in a Korean cohort. Sleep 2013;36:369-376.

4. Knutson KL, Spiegel K, Penev P, Van Cauter E. The metabolic consequences of sleep deprivation. Sleep Med Rev 2007;11:163-178.

5. Spiegel K, Tasali E, Penev P, Van Cauter E. Brief communication: sleep curtailment in healthy young men is associated with decreased leptin levels, elevated ghrelin levels, and increased hunger and appetite. Ann Intern Med 2004;141:846-850.

6. Strine TW, Chapman DP. Associations of frequent sleep insufficiency with health-related quality of life and health behaviors. Sleep Med 2005;6:23-27.

7. Kroese FM, Evers C, Adriaanse MA, de Ridder DTD. Bedtime procrastination: a self-regulation perspective on sleep insufficiency in the general population. J Health Psychol 2016;21:853-862.

8. Kroese FM, De Ridder DT, Evers C, Adriaanse MA. Bedtime procrastination: introducing a new area of procrastination. Front Psychol 2014; 5:611.

9. Solomon LJ, Rothblum ED. Academic procrastination: frequency and cognitive-behavioral correlates. J Couns Psychol 1984;31:503-509.

10. Steel P. The nature of procrastination: a meta-analytic and theoretical review of quintessential self-regulatory failure. Psychol Bull 2007;133: 65-94.

11. Tice DM, Baumeister RF. Longitudinal study of procrastination, performance, stress, and health: the costs and benefits of dawdling. Psychol Sci 1997;8:454-458.

12. Steel P, Brothen T, Wambach C. Procrastination and personality, performance, and mood. Pers Individ Dif 2001;30:95-106.

13. Stead R, Shanahan MJ, Neufeld RWJ. "I'll go to therapy, eventually": procrastination, stress and mental health. Pers Individ Dif 2010;49: 
175-180.

14. Schraw G, Wadkins T, Olafson L. Doing the things we do: a grounded theory of academic procrastination. J Educ Psychol 2007;99:12-25.

15. Sirois FM, Melia-Gordon ML, Pychyl TA. "I'll look after my health, later": an investigation of procrastination and health. Pers Individ Dif 2003;35:1167-1184.

16. Sirois FM. "I'll look after my health, later": a replication and extension of the procrastination-Health model with community-dwelling adults. Pers Individ Dif 2007;43:15-26.

17. Chung SJ, An H, Suh S. What do people do before going to bed? A study of bedtime procrastination using time use surveys. Sleep 2020; 43:Zsz267.

18. Shin JH, Ha HS. Changes in media possession and usage in the year of 2011 through 2014. Jincheon: Korea Information Society Development Institute, 2014.

19. Kim EM, Shim MS, Kim BY, Oh HY. The mediatization of everyday life: focus group interviews of "smart" media users. Korean Journal of Journalism \& Communication Studies 2012;56:133-159.

20. Gradisar M, Wolfson AR, Harvey AG, Hale L, Rosenberg R, Czeisler CA. The sleep and technology use of Americans: findings from the National Sleep Foundation's 2011 sleep in America poll. J Clin Sleep Med 2013;9:1291-1299.

21. Exelmans L, Van den Bulck J. Electronic media use and the blurriness of bedtime: introducing sleep displacement as a two-stage process. $J$ Sleep Res 2016;25 Suppl 1:149.

22. Exelmans L, Van den Bulck J. Bedtime mobile phone use and sleep in adults. Soc Sci Med 2016;148:93-101.

23. Fossum IN, Nordnes LT, Storemark SS, Bjorvatn B, Pallesen S. The association between use of electronic media in bed before going to sleep and insomnia symptoms, daytime sleepiness, morningness, and chronotype. Behav Sleep Med 2014;12:343-357.

24. Orzech KM, Grandner MA, Roane BM, Carskadon MA. Digital media use in the $2 \mathrm{~h}$ before bedtime is associated with sleep variables in university students. Comput Human Behav 2016;55:43-50.

25. Jeong YC. Intergenerational changes in media use and spread of smart phones. Korea Information Society Development Institute 2015;15:1-8.

26. Jung $\mathrm{H}$, Song $\mathrm{H}$. The mediating effects of smartphone overuse in relation between existential vacuum and bedtime procrastination. The Journal of Humanities and Social Science 2018;9:441-456.

27. Elhai JD, Dvorak RD, Levine JC, Hall BJ. Problematic smartphone use: a conceptual overview and systematic review of relations with anxiety and depression psychopathology. J Affect Disord 2017;207:251-259.

28. Lemola S, Perkinson-Gloor N, Brand S, Dewald-Kaufmann JF, Grob A. Adolescents' electronic media use at night, sleep disturbance, and depressive symptoms in the smartphone age. J Youth Adolesc 2015;44: 405-418.

29. Jenaro C, Flores N, Gómez-Vela M, González-Gil F, Caballo C. Problematic internet and cell-phone use: psychological, behavioral, and health correlates. Addict Res Theory 2007;15:309-320.

30. Tamura H, Nishida T, Tsuji A, Sakakibara H. Association between excessive use of mobile phone and insomnia and depression among Japanese adolescents. Int J Environ Res Public Health 2017;14:701.

31. Christensen MA, Bettencourt L, Kaye L, et al. Direct measurements of smartphone screen-time: relationships with demographics and sleep. PLoS One 2016;11:e0165331.

32. Harriott J, Ferrari JR. Prevalence of procrastination among samples of adults. Psychol Rep 1996;78:611-616.

33. Ministry of Science and ICT. The survey on smartphone overdependence (2018). Statistics Korea, 2019 Jan [cited 2019 Feb 17]. URL:http:// kostat.go.kr/portal/korea/kor_pi/8/6/2/index.board?bmode=read\&aS eq $=372667$ \&pageNo=14\&rowNum $=10 \&$ amSeq $=\&$ sTarget $=\&$ sTxt $=$.

34. Bastien CH, Vallières A, Morin CM. Validation of the Insomnia Severity Index as an outcome measure for insomnia research. Sleep Med 2001;2:297-307.

35. Cho YW, Song ML, Morin CM. Validation of a Korean version of the Insomnia Severity Index. J Clin Neurol 2014;10:210-215.

36. Radloff LS. The CES-D scale: a self-report depression scale for research in the general population. Appl Psychol Meas 1977;1:385-401.

37. Chon KK, Choi SC, Yang BC. Integrated adaptation of CES-D in Korea. Kor J of Psychol: Health 2001;6:59-76.

38. Oh YK. A study on the influence of SNS addiction tendency on loneliness, depression, interpersonal relationship and social support [dissertation]. Seoul: Korea Counseling Graduate University;2012.

39. Cho SH, Suh KH. An exploratory study on factors related with SNS addiction proneness: focus on covert narcissism, self-presentational motivation, and sense of alienation. Kor J of Psychol: Health 2013;18:239-238.

40. Enez Darcin A, Kose S, Noyan CO, Nurmedov S, Yllmaz O, Dilbaz N. Smartphone addiction and its relationship with social anxiety and loneliness. Behav Inf Technol 2016;35:520-525.

41. Kim UC, Hong CS, Lee JG, Park YS. Factors influencing health and quality of life among allergy and asthma patients: with specific focus on self-efficacy, social support and health management. Korean Journal of Psychological and Social 2005;11:143-181.

42. Jang $\mathrm{CH}$, Kim SH, Oh DH. Cognitive behavioral therapy of insomnia. Hanyang Med Rev 2013;33:210-215.

43. Ree MJ, Harvey AG, Blake R, Tang NK, Shawe-Taylor M. Attempts to control unwanted thoughts in the night: development of the thought control questionnaire-insomnia revised (TCQI-R). Behav Res Ther 2005; 43:985-998.

44. Brunborg GS, Mentzoni RA, Molde H, et al. The relationship between media use in the bedroom, sleep habits and symptoms of insomnia. $J$ Sleep Res 2011;20:569-575.

45. Morin CM, Bootzin RR, Buysse DJ, Edinger JD, Espie CA, Lichstein KL. Psychological and behavioral treatment of insomnia: update of the recent evidence (1998-2004). Sleep 2006;29:1398-1414. 